\title{
Welcome to Romania!, A Philatelic Retrospective on the Most Valuable Elements of the National Cultural Heritage
}

\author{
Bogdan-Vasile Cioruța ${ }^{1^{*}}$ \\ ${ }^{1}$ Technical University of Cluj-Napoca, North University Centre of Baia Mare, Office of Informatics, $62 \mathrm{~A}$ \\ Victor Babeș street, 430083, Baia Mare, Romania.
}

Author's contribution

Author BVC designed the study, performed the literature searches, and wrote the first draft of the manuscript. Author also managed the analyses of the entire study, read and approved the final

manuscript.

Article Information

DOI: 10.9734/AJGR/2021/v4i130125

Editor(s):

(1) Dr. Xu Chong, Institute of Geology, China.

(2) Dr. Huan Yu, Chengdu University of Technology, China

Reviewers:

(1) Saeed Nosratabadi, Szent István University, Hungary.

(2) Daniela Freire Sousa Ribeiro, Universidade Federal do Recôncavo da Bahia, Brazil.

(3) Suhaimi Bin Hassan Fakulti Kejuruteraan, Universiti Tun Hussein Onn Malaysia (UTHM), Malaysia

(4) Mahfuzul Haque, Bangladesh University of Professionals (BUP), Bangladesh.

Complete Peer review History: http://www.sdiarticle4.com/review-history/65276

Original Research Article

Received 15 December 2020

Accepted 21 February 2021

Published 16 March 2021

\section{ABSTRACT}

One of the most beautiful countries in Europe, Romania, offers many travel experiences that are just waiting to be discovered. The words that best describe the essence of Romania are authentic, natural, and cultural, being a country rich in history, art, and natural beauty. As a part of Europe, Romania has often earned its reputation as a country with special cultural and spiritual values. Most often, however, it has been noted in terms of people who have sanctified the places, in terms of places and monuments that delight our eyes, but especially in terms of biodiversity in protected areas recognized nationally and internationally. The purpose of this study is to present the implications of philately in promoting Romania abroad. In this sense, an attempt was made to expose a series of different philatelic effects. The pieces in question (postage stamps, First Day Covers - FDCs, maximum postcards, special envelopes and covers, etc.) that appeared on the occasion of various philatelic issues, come to warmly greet the visitor and entice him to visit these places. Moreover, through these philatelic materials (collected, indexed, and analyzed based on

*Corresponding author: E-mail: bogdan.cioruta@staff.utcluj.ro; 
specialized catalogs and platforms with philatelic content), it was wanted to show that our country (Romania) is not just a Carpathian garden, but a European treasure, which transcends over the centuries through beauty and spirituality. No less than four reference philatelic issues have been discovered for the period 2009-2020, which support the idea of visiting the country, as well as the possibility to practice special cultural tourism.

Keywords: Romanian philately; outstanding personalities; protected areas; welcome theme.

\section{INTRODUCTION}

In the southeastern part of Central Europe, formed on the old heart of Dacia and on the arch of the Carpathian mountains in the middle, bordered by the Danube and the Black Sea, are Romania and the Romanian people, a stable people over two thousand years old [1]. With a rich history, the current territory of Romania offers the tourist opportunity to discover some of the oldest and richest evidence of spirituality, traditions, continuity and authentic culture.

Romania is the country of famous wooden churches, especially those in Maramureș, and of the only cheerful cemetery (with the necessary quotation marks) in the world, the one in Săpânța, but also the country of numerous historical monuments whose uniqueness amazes any visitor at every step [1,2]. The Romanian folk creation is known by all the continents of the world, through its variety and uniqueness. It is also represented by the folk pottery and the beauty of the folk costumes. Having almost all the forms of relief existing in nature [3], thousands of rivers and hot springs, parks, and nature reserves, famous and unique caves in Europe and the Black Sea coast, Romania presents its beauties in a chain of important points on the tourism map of Europe.

The arguments presented above come to indicate that Romania deserves to be visited for the uniqueness of its beauties and the many traditions preserved over the centuries. Furthermore, the philatelic issues that we have studied, through the thematic structure, the dynamics of the circulation, and the attractive design come to give a well-deserved place to our country within the other European Union states, in terms of culture, traditions, famous personalities, and places and landscapes in protected natural areas.

\section{MATERIALS AND METHODS}

This paper started from a series of philatelic issues, which wanted to promote from the very beginning the natural, cultural, and spiritual heritage of Romania as well. The philatelic issues to which we refer appeared, as an ambassador of our country's heritage, and were recorded as such, starting with 2009, when for the first time the "Romania - a European treasure" theme was exposed. Of course, other shows followed, following approximately the same guideline (promoting Romania as a European brand space). For the most part, they pleasantly surprised the general public, as they referred to a multitude of elements specific to Romanian history, geography, culture, and spirituality.

The choice, indexing, and analysis of philatelic issues, and the elements they encompass (postage stamps, "first day of issue" covers, souvenir packages, stamp blocks, postcards, and other philatelic effects) were made through the official website of Romfilatelia. This was also the point of reference in the study undertaken.

Along with the useful information, we managed to gather the following Romfilatelia platforms, including from various other platforms with philatelic content (Allnumis, Colnect, Delcampe, eBay, Okazii, PicClick, StampWorld), a former and former discussion with various collectors, at the level of social platforms or discussion forums. Thus, only those shows were chosen that capitalize through the reproduced content the idea that Romania is still a well-defined space, with many values, from a socio-cultural perspective and not only. The most diverse philatelic effects from 2009-2019 were therefore taken into account, representing world-renowned personalities, cultural institutions or places of worship frequently visited by tourists, monuments of nature unique in Europe, and many more.

\section{RESULTS AND DISCUSSION}

\subsection{Romania - a European Treasure, 2009}

As previously mentioned, in the south-eastern part of Central Europe, with the arch of the 
Carpathian Mountains in the middle, there is, for over two thousand years, a community with a rich and tumultuous history [4]. About the history, the occupations of the locals, and the beauties of our homeland, over time, a series of philatelic issues were connected, the vast majority of them under the aegis of Romfilatelia.

The first of these, which wanted to emphasize the importance of Romania in the current European context, appeared on 16.09.2009 under the title "Romania - a European treasure". Composed of not less than 8 postage stamps in $42 \times 27 \mathrm{~mm}$ format, laced 131/2 (Mi RO\#6385..92, WAD RO\#044.09..051.09, Rom RO\#1844 (1)..(8)) [5,6], commemorative issue, made by offset lithography, comes to justify the patrimony value of Romania, a value also recognized at the international level, not only European.

The eight postage stamps, illustrated in Fig. 1 $[7,8]$, and made according to the models of $M$. Vămășescu and $S$. Pelteacu refer to famous personalities of the Romanian culture, to cultural buildings, to protected natural areas recognized and appreciated internationally, and of course, to activities and crafts that have consecrated various regions of the country.

Romfilatelia strives to add to each postage stamp issue - such as the current one - a drop of this source, inexhaustible and not yet fully discovered, of Romanian spirituality and culture. The eight postage stamps of the issue, each with a face value of 3.00 lei, illustrate the unique and authentic riches for which Romania is known all over the world.

Dimitrie Cantemir (1673-1723) was a remarkable personality of the European culture at the beginning of the XVIII century. Lord of Moldova, historian, philosopher, geographer, musicologist, orientalist, theologian, cartographer, prose writer, and polyglot, Dimitrie Cantemir, through his works, established himself as a world-class scholar and encyclopedist (see Fig. 1a). Dimitrie Cantemir, a personality with encyclopedic preoccupations, was the first Romanian member of the Berlin Academy (1714) - at the request of this Academy he wrote: "Descriptio Moldaviae" - the first work on politics, geography, ethnography, and folklore. "Prince Serenism" of Russia and a secret adviser to Tsar Peter I, through his vast work, is considered an illustrious scientist of the Renaissance.

George Enescu (1881-1955), a complex musician, managed to give to universal music all his feelings, thoughts, in such a way that everything always merged with the echo of his soul. Bucharest, Vienna, Paris, New York, London, Berlin, Chicago, Boston, Cincinnati, Philadelphia, Strasbourg - are among the great musical cities of the world where Enescu's music resounded (see Fig. 1b). Sheet music, suites, symphonies, quartets, rhapsodies, lieds, and operas - all are creations of the great composer, conductor, violinist, pianist, and teacher, George Enescu - the immortal voice of Romania.

The Church of the Holy Three Hierarchs in Iaşi, a unique edifice in Romanian architecture, founded by Prince Vasile Lupu, was initially part of a monastic ensemble (see Fig. 1c). The Church of the Holy Three Hierarchs has aroused the admiration of all since its inauguration in 1639. The motifs that adorn the facade are of Armenian-Georgian influence. The windows are decorated with cornices and canopies. The decorative elements on the outside, of incomparable richness, give the impression of a real stone embroidery. The Church of the Holy Three Hierarchs houses the tombs of Vasile Lupu, the voivode, and scholar Dimitrie Cantemir, as well as the bones of Prince Alexandru loan Cuza.

The Black Church in Brasov was built around 1380 and is known as the Church of St. Mary. The building was partially destroyed during the Great fire of 1689, which gave it its current name (see Fig. 1d). The Black Church is the largest Gothic-style cult building in Southeast Europe, measuring 89 meters long and 38 meters wide. The Black Church is famous not only for its size but also for the fact that the bell tower is the largest bell in Romania, a bronze bell weighing 6 tons. At the same time, the Black Church has its large organ with about 400 tubes, this being one of the largest in South-Eastern Europe. The collection of oriental carpets of the Black Church is the richest of its kind in Romania. Very close to the Black Church is the statue of the humanist Johannes Honterus, the work of the Berlin sculptor $\mathrm{H}$. Magnussen.

The Danube Delta, the only delta in the world declared a biosphere reserve, is also considered one of the largest wetlands in the world, as a habitat for waterfowl, where the pelican - a symbol of the Danube Delta - lives here in the largest colony in Europe (Fig. 1e). A magical land of waters, the Danube Delta is considered one of the most fascinating natural areas in the world. 


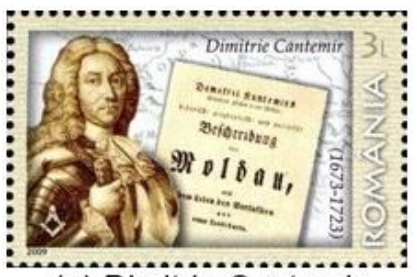

(a) Dimitrie Cantemir (1673-1723)

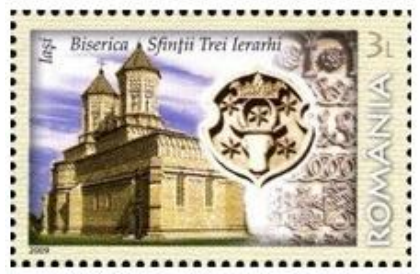

(d) The Three Saint Hierarchs Church, Iași

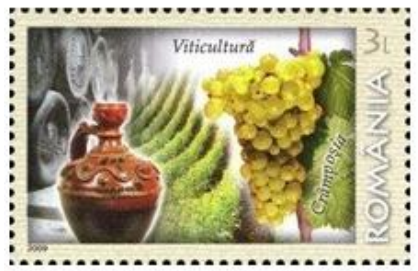

(g) Viticulture

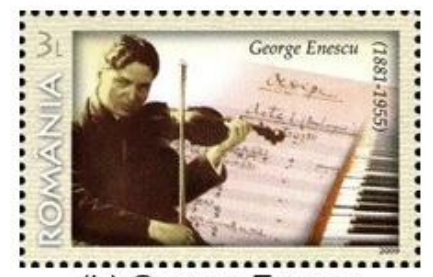

(b) George Enescu (1881-1955)

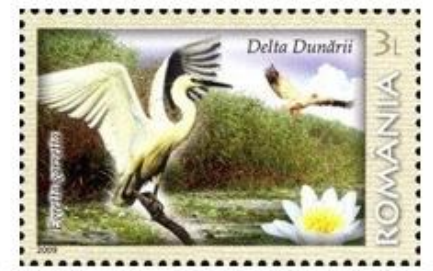

(e) Danube Delta: Little Egret (Egretta garzetta), Water Lily

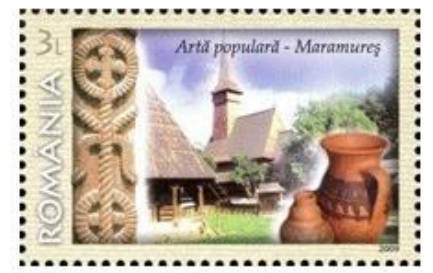

(h) Popular Art in Maramureș

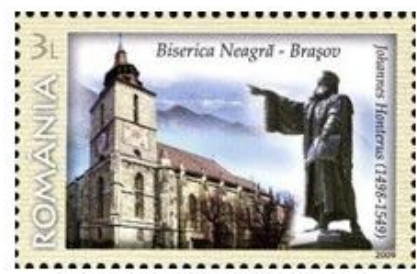

(c) The Black Church, Brașov

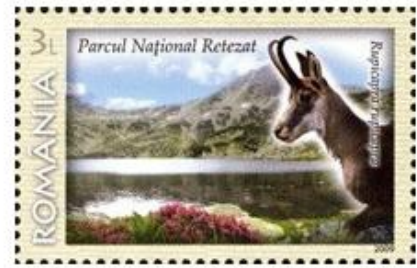

(f) Retezat National Park: Chamois

(Rupicapra rupicapra)

Fig. 1. Postage stamps of the philatelic issue "Romania - a European treasure", 16.09.2009, Bucharest $[7,8]$

The most important mountain nature reserve in our country, the biosphere reserve, Retezat National Park adds to the diversity of Romania's invaluable natural resources (see Fig. 1f). Places still untouched by man, high peaks, lakes, glaciers, caves, vast forests - all gather in a unique monument of nature: Retezat National Park.

On one of the stamps is illustrated an old Romanian grape variety, Crâmpoşia, knowing that in Romania, viticulture is over two thousand years old (see Fig. 1g). As it is known, at the beginning of the $1^{\text {st }}$ century $\mathrm{BC}$. Viticulture had taken on such a scale, with the creation of the first centralized and independent Dacian state, that King Burebista undertook some actions to limit the cultivation of vines. On the territory of our country, viticulture has been favored both by climate and soil conditions and especially by solar radiation. The Crâmpoşia wine variety is found in the well-known Drăgãşani vineyard. The wine is white, dry, balanced, full of freshness, and can compete with any other wine in the world.
The hearth of culture and civilization, Maramureş has carved its history in wood through the popular art of Maramureş.Maramureş is the place where traditions, dress, and folk art are best preserved in Romania (see Fig. 1h). As a return to time, Maramureş is a large open-air museum. The wooden churches - true masterpieces of folk art - are found in almost every village, and the Maramures gate, this wooden "triumphal arch", is found in every house. The tradition of ceramics lasts from the time of the Dacians and has not changed much in terms of technique, ornamentation, and shapes.

The philatelic issue having a modest circulation (only 18,000 complete series) for such a large number of pieces (eight stamps already exposed and presented), is accompanied by a mini-sheet and a block-pack, respectively, by two FDCs, all reproduced in Fig. 2 [7-10]. Regarding the colitis, it summarizes the entire philatelic issue on a gray background, which resumes in the central part the image of the stamps on either side of the infinity column, another tourist reference point for Romania. 
The FDCs of the issue, on the other hand, present on a blue background the Sphinx from Bucegi, another landmark very well known to those who visit our country. Moreover, with some of the postage stamps described above, a special envelope was commemorated in the official regime, even by Romfilatelia, to commemorate the Cultural Days of the European Central Bank. This material is reproduced both in the uncirculated version, bearing the stamp "the first day of the issue" (Fig. 3a) [11-13], and in the circulated version (Fig. 3b) [14].

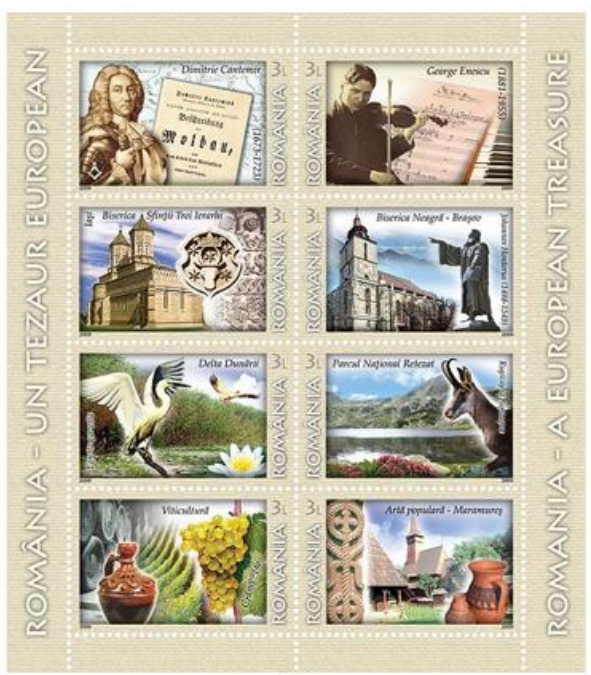

(b)

(a)

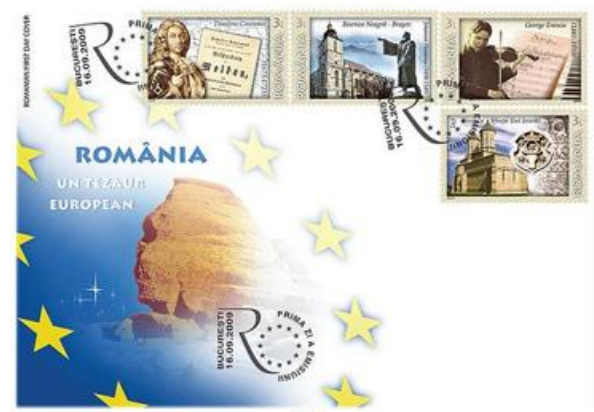

(c)

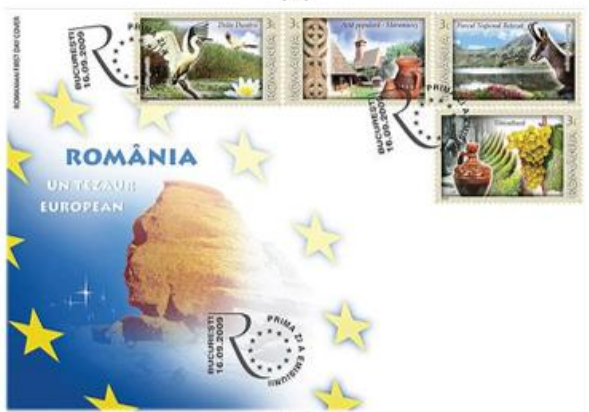

(d)

Fig. 2. The mini-sheet, the 8-stamp block and the FDCs of the philatelic show "Romania - a European treasure", 16.09.2009, Bucharest $[9,10]$

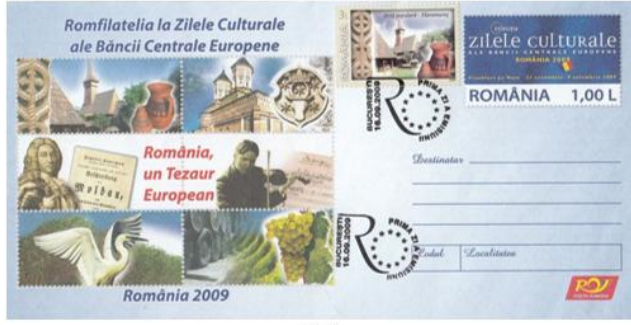

(a)

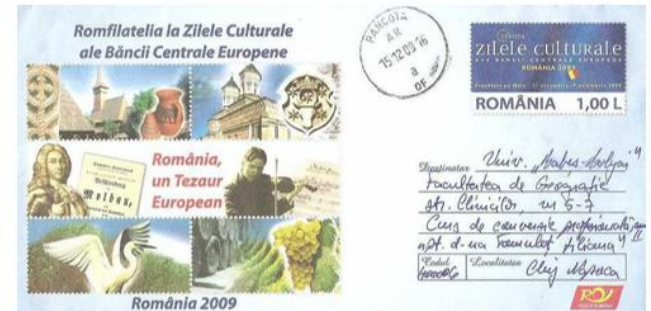

(b)

Fig. 3. Special envelope bearing the postage stamps of the philatelic issue "Romania - a European treasure", 16.09.2009, Bucharest [11-14] 


\subsection{Welcome to Romania!, 2017}

Romfilatelia, under the motto of "a world in a stamp", invites connoisseurs through the second show, entitled "Welcome to Romania!" (LP \#2154), to take an imaginary walk through our country. Through this philatelic issue, published on 26.07.2017, those interested are guided to explore the architectural treasures of the country and enjoy the rich cultural heritage [15]. The 6 postage stamps that make up the issue (see Fig. 4) [16-17], in $48 \times 33 \mathrm{~mm}$ and $33 \times 48 \mathrm{~mm}$ format, only in lacy version, were made by offset lithography, in 4 colors on chrome-gummed paper.

The stamp with a face value of 2.50 lei reveals a landscape of the Danube Delta. It became a UNESCO World Heritage Site in 1991 as a Biosphere Reserve (Fig. 4a). It includes one of the largest wetlands in the world, with over 400 lakes, oak and ash forests, sand dunes and wild beaches on the deltaic sea coast. In this space, the little egret (Egretta garzetta) makes its home. It nests in colonies in fresh or saline waters and shows a preference for shallower waters, where fish concentrate on the surface of the water.
The stamp with a face value of 2.70 lei depicts the Clock Tower in the city of Sighișoara, the most massive of the nine defense towers of the fortress that have been preserved so far (Fig. 4b). The whole city, one of the few inhabited medieval fortress cities, appears to the visitor as an open-air museum, its exhibits, charming through the atmosphere they create together, attracting hundreds of thousands of tourists every year. Next to the medieval city, we have Saxon pottery, which stands out in terms of ornamental details, through a generous repertoire of decorative motifs.

The stamp with a face value of 3.50 lei illustrates the Bigăr Waterfall which is part of a protected area, located in Caraş-Severin County, Bozovici commune (Fig. 4c). Its source is a strong one, fed by an underground watercourse that crosses the Anina Mountains. After about $200 \mathrm{~m}$, the spring water flows into the Miniș River from a rocky threshold, forming a spectacular waterfall. The beauty of this area is represented by the majestic Carpathian deer, which can be found in areas with large forests, rich in food sources.

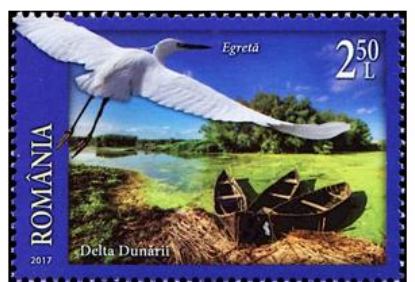

(a) Danube Delta \& egret

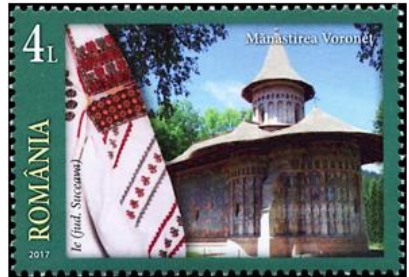

(d) Voroneț Monastery \& ie (Suceava County)

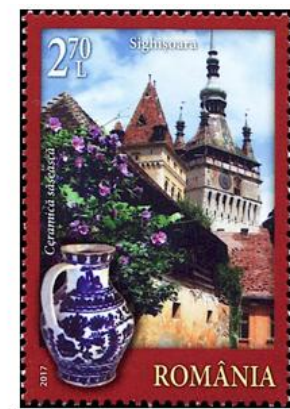

(b) Sighisoara \& Saxon ceramics

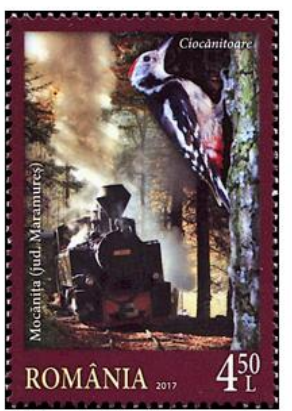

(e) Mocănița (Maramureș County) \& woodpecker

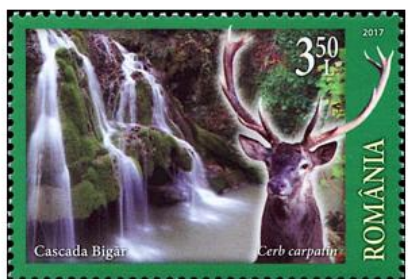

(c) Bigar Waterfall \& Carpathian deer

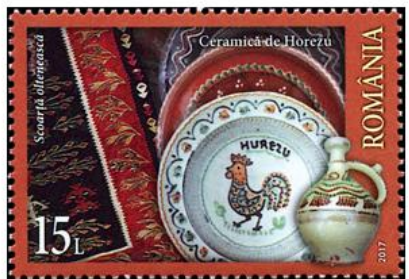

(f) Horezu pottery \& Oltenian bark

Fig. 4. Stamps of "Welcome to Romania!" issue, 26.07.2017, Bucharest [16,17] 
The stamp with a face value of 4 lei illustrates the Voroneţ Monastery, a medieval monastery in the town of Gura Humorului. Often known as the "Eastern Sistine Chapel", the frescoes at Voronet have an intense shade of blue, known in Romania as "Voroneţ blue" (Fig. 4d). This is one of the famous painted monasteries in southern Bukovina, in Suceava County. The monastery was built by Stephen the Great in 1488, to commemorate the victory at the Battle of Vaslui. Next to the monastery, we find an ie with a model specific to the Suceava area. To make it, the materials are chosen carefully, and the places of each model are strictly established. The ornaments, colors, and materials from which they were made represented a social mark - civil, marital, confessional, and zonal status.

The stamp with a face value of 4.50 lei depicts the Mocăniţa and the splendid natural decoration through which it makes its way. A mocăniţă is a narrow-gauge Romanian railway, found especially in Maramureș, Transylvania, and Bucovina. They are usually located in mountainous areas, and the steam locomotives that operate on them can also be called mocanites (Fig. 4e). These railways were built for freight and passenger services (before 1920) but have been abandoned over the years. Some are rehabilitated for tourist purposes, giving travelers a chance to take a walk through the mountain nature. One of the most beloved birds by children and the easiest to recognize even from the train is the middle woodpecker, the "forest doctor".

The craft of Horezu pottery, inscribed in 2012 by UNESCO on the List of Intangible Cultural Heritage of Humanity, is a unique traditional craft. Handmade in the northern part of Vâlcea County, Romania, the pottery reflects generations of craftsmanship (Fig. 4f). The men choose and extract the earth, which is then transformed into a clay body from which the potters from Horezu produce red pottery. Women decorate objects using specific techniques and tools to draw traditional motifs. Their ability to combine decoration with color defines the personality and uniqueness of this type of ceramic, illustrated on the stamp with a face value of 15 lei. Along with the Horezu pottery, we have a peasant bark whose color and decorative pattern is specific to the Oltenia area.

The circulation of 187,080 stamps was managed in sheets of 32 stamps $(127,680$ stamps), in blocks of 5 stamps +1 vignette $(6,840$ ministamps, the equivalent of 34,200 stamps), as shown in Fig. 5 [15], and a block of 6-stamps $(4,200$ blocks, the equivalent of 25,200 stamps $)$. In addition to the postage stamps and the blocks with stamps modeled by $\mathrm{M}$. Vămășescu, we wanted to present and reproduce the two FDCs equipped with the stamps of the issue, numbered and obliterated with the stamp "the first day of the issue" (see Fig. 6a), the souvenir package (Fig. 6b), as well as the 6 maximum postcards (Fig. 6c) that fully accompany and characterize the issue [15].

\subsection{Romania, a European Treasure, 2019}

Somewhere in the southeastern part of Central Europe, bathed by the waves of the Black Sea and bordered on the south by the Danube, heated at the waist by the arch of the Carpathian Mountains, remains for over 2000 years, one of the most beautiful countries [18]. In the context of taking over, on January 1, 2019, the Romanian Presidency of the Council of the European Union, Romfilatelia through the philatelic show "Romania, a European treasure" (LP \#2226), practically invites those interested to (re) discover the indisputable values of our country, which has stood out both in Europe and around the world, through its rich cultural, spiritual and scientific heritage.

Published on 16.01.2019, the philatelic issue consists of 6 postage stamps [18-20]. Printed in a $52 \times 42 \mathrm{~mm}$ format, laced by offset lithography in 4 colors on chromed gummed paper, after a series of models made by $M$. Vămășescu, the postage stamps capture other unique aspects of Romania. Through the generous circulation of 132,520 stamps [18], organized in sheets of 20 $(47,320$ stamps $)$, in mini-stamps of 5 stamps +1 vignette $(9,240$ mini-stamps, the equivalent of 46,220 stamps) and a block of 6 unlined stamps $(6,500$ blocks, equivalent of 39,000 stamps $)$, the issue is large-scale.

On the stamp with a face value of 2 lei, you will discover the personality of the greatest Romanian sculptor, who marked the 20th century. Titan of world art, the Romanian sculptor Constantin Brâncuși (1876-1957) is presented with some of his works. A follower of modern abstract sculpture, Constantin Brâncuși, influenced and revolutionized, defining, and unanimously recognized sculpture. His works in bronze and marble are characterized by a pure, elegant, and restrained form, but also by a 
refined finish (Fig. 7a). Passionate about wood carving, he made numerous works, some of them folk-inspired, and often carved wooden prototypes for works, later executed in other materials. His international recognition came relatively quickly, and many of his works, such as Bird in the Air, Miss Pogany, or Princess X, became his passport to the world's largest sculpture exhibition. An exceptional creation is represented by the brilliant sculptural complex of Târgu Jiu, dominated by the Infinity Column. The National Museum of Modern Art in Paris Center Pompidou houses an important number of works by the artist.

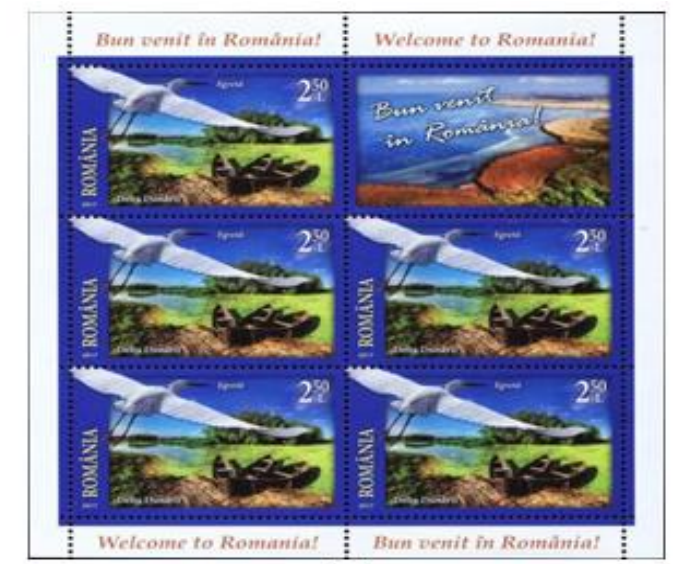

(a)

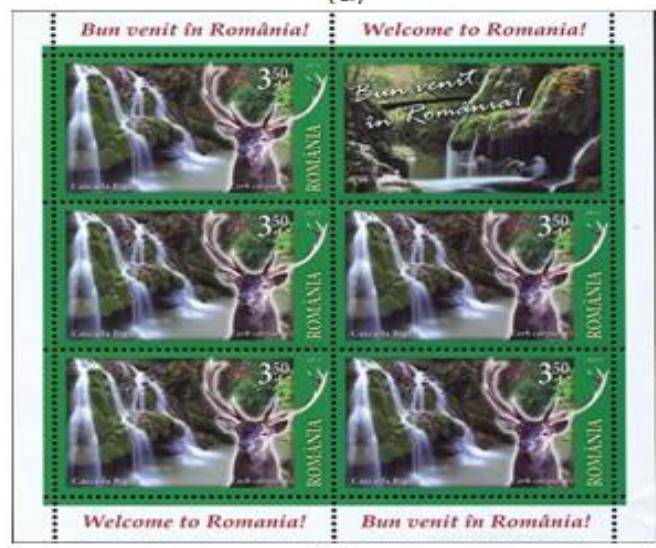

(c)

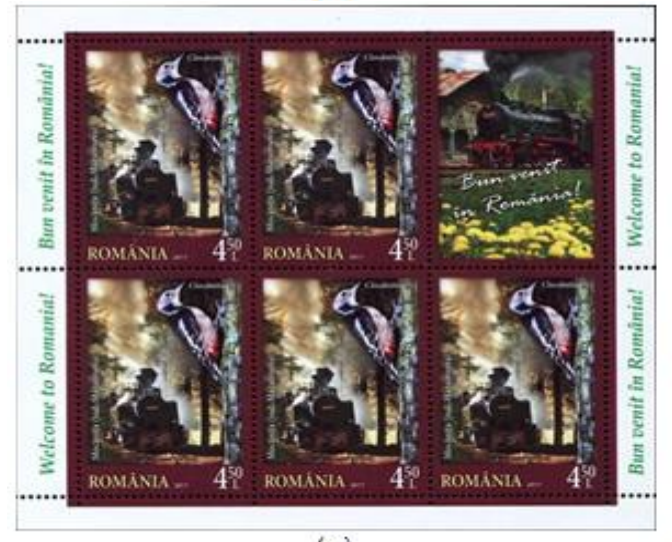

(e)

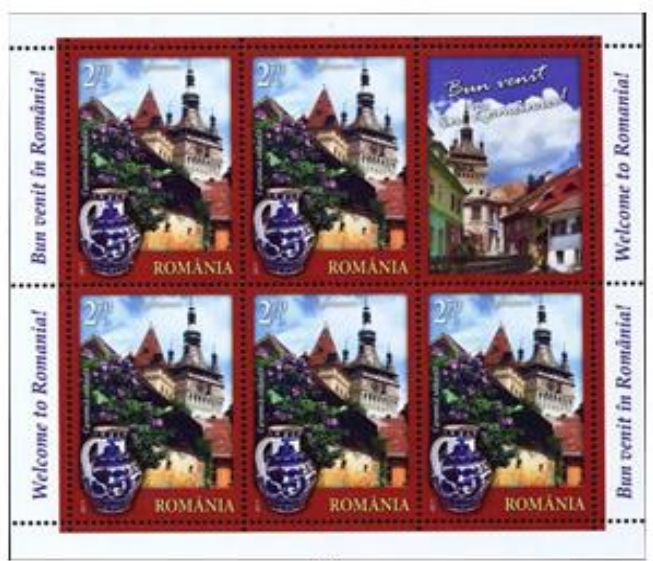

(b)

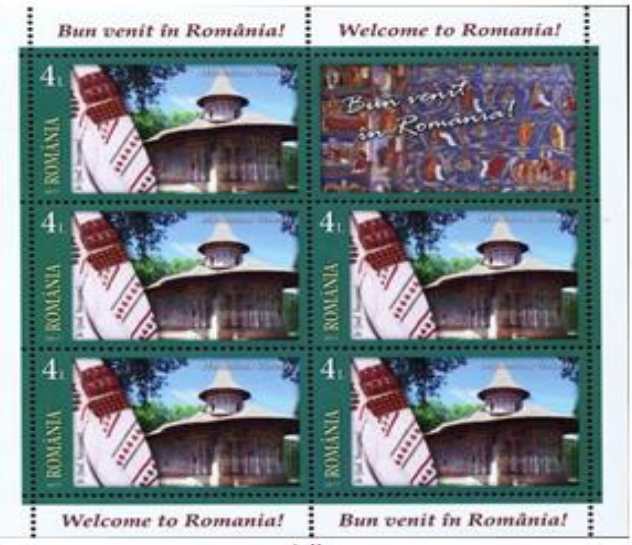

(d)

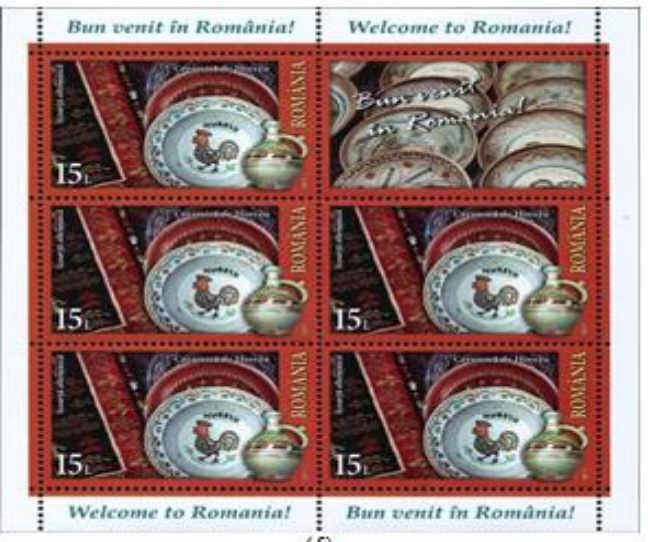

(f)

Fig. 5. The blocks of $5+1$ postage stamps of the philatelic issue "Welcome to Romania!", 26.07.2017, Bucharest 


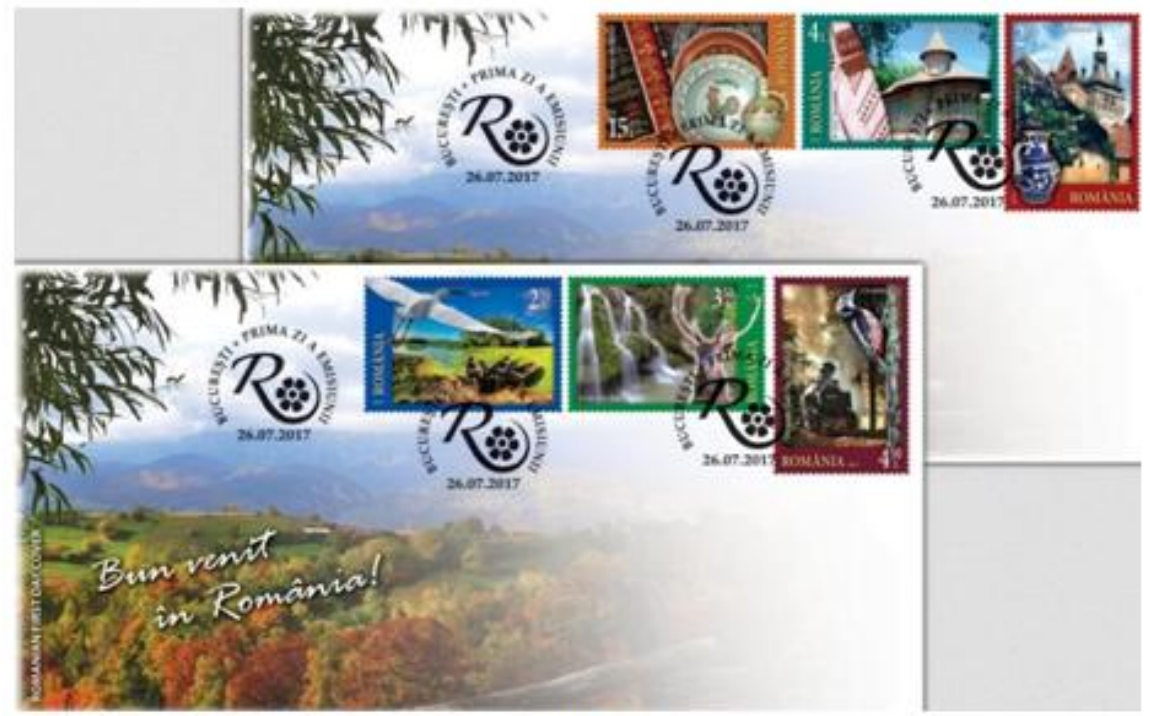

(a)

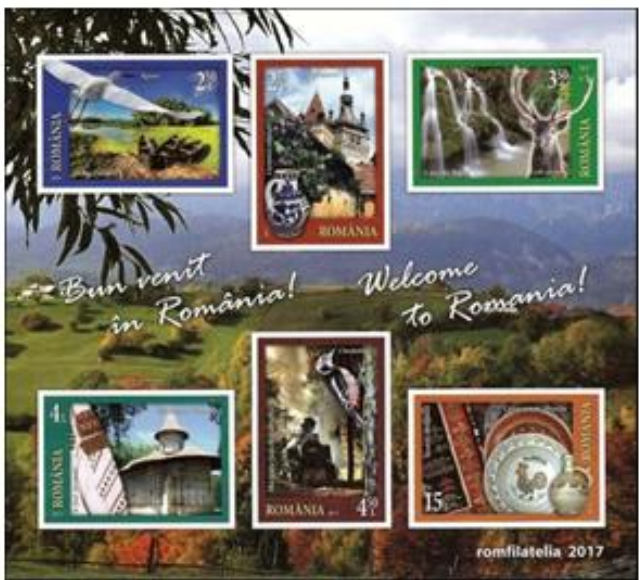

(b)

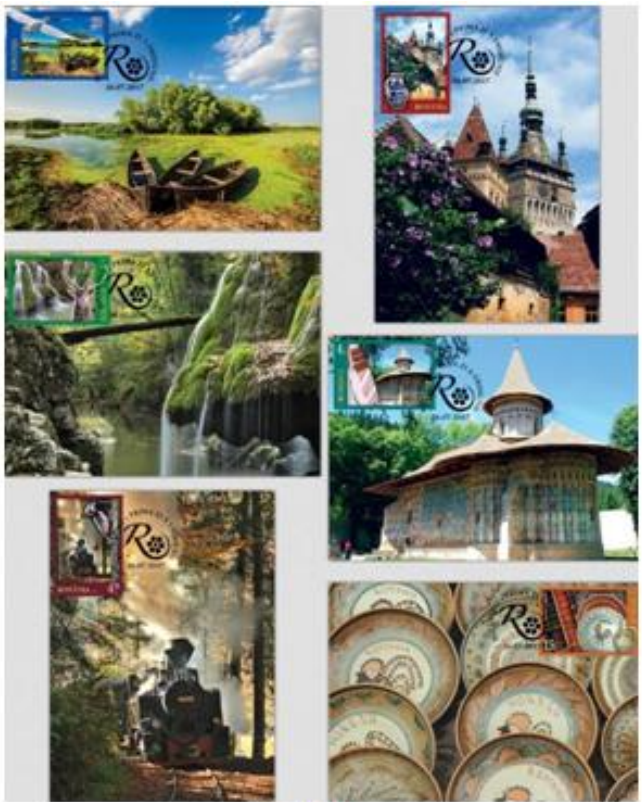

(c)

Fig. 6. The two FDCs, the souvenir package and the 6 official maxims of the philatelic issue "Welcome to Romania!", 26.07.2017, Bucharest

Bucharest, part of the historical province of Muntenia, first mentioned in 1459, and the capital of Romania since 1862, as an important political, economic, commercial, and tourist center, stands out for its architecture. It reflects the varied history of the city through a harmonious blend of traditional and modern (Fig. 7b). In the interwar period, French influences in the culture and elegant architecture of the city gave it the nickname "Little Paris". The
Romanian Athenaeum, built in the Baroque style between 1886-1888, a monument included in the European Heritage List, is one of the most beautiful buildings in Bucharest. Symbol of Romanian culture, this building houses the "George Enescu" Philharmonic, being represented on the stamp with a face value of 2.60 lei. The decorative sculptures executed by Italian and German artists, the vast hall with twelve Doric metal columns clad in pink stucco, 
as well as the four interior stairs leading to the concert hall, impress with their pomp. Also, the facade of the building exhibits medallions made in mosaic with the figures of some notable Romanian rulers.

Considered one of the great inventors of the twentieth century, the one who revolutionized the aeronautical industry, Henri Coandă (18861972), a Romanian engineer and physicist, is illustrated on the stamp with a face value of 2.90 lei (Fig. 7c). Throughout his career, he has distinguished himself by amazing creativity, embodied in over 250 patents, with applications in various fields that have brought him numerous international awards and academic titles. At the Second International Aeronautics Show in Paris in 1910, he exhibited his turboprop. We are talking about the first jet plane, the forerunner of today's turbojet planes, through which Henri Coandă became the father of jet aviation. Coanda's fame is due to the discovery of the effect of the fluid mechanism, which today bears his name. Thus, the Coandă Effect, patented in 1934 under the name Method and device for diverting a fluid into another fluid, revolutionized aeronautics. Academician, engineer, aviation pioneer and inventor, member of the Royal Aeronautical Society of London and the Romanian Academy, Doctor
Honoris Causa of the Bucharest Polytechnic Institute, Henri Coandă passed away on November 25, 1972.

The youngest land in Europe, the Danube Delta, the gift that the river offered to Romania, entered the UNESCO World Heritage Site in 1991, as a Biosphere Reserve. The area comprises one of the largest wetlands in the world, with over 400 lakes, oak and ash forests, dunes, and wild beaches on the deltaic seashore (Fig. 7d). In the delta, a varied and dense aquatic flora developed, the courses of the main arms being bordered by a wide curtain of willows, while on the land portions forests of hard essences developed. In this exotic land with over 1,800 plant species, the Letea Forest stands out, the oldest nature reserve in Romania, which covers about 3,200 ha. Considered the "little jungle" of the Danube Delta, it is the northernmost subtropical forest and the only place in Europe where vines are found. The fauna of the Delta is particularly rich comprising over 300 species of birds, of which over 70 migratory, about 40 species of mammals, but also over 130 species of fish, an important source of food for birds and aquatic mammals, as well as an important scientific and economic resource. The stamp with a face value of 3 lei shows one of the wonderful landscapes of the Danube Delta.

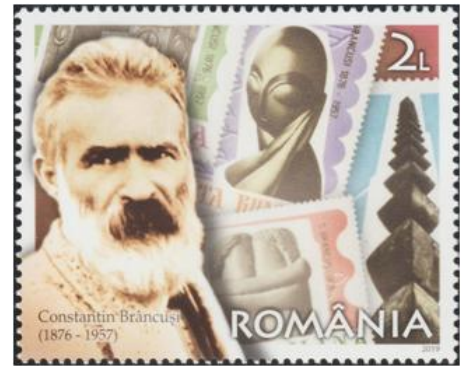

(a) Constantin Brâncuși (1876-1957)

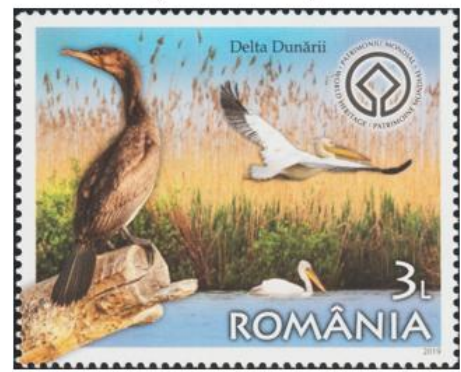

(d) The Danube Delta

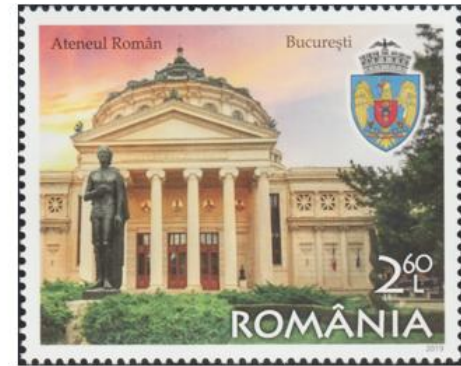

(b) Romanian Athenaeum, Bucharest

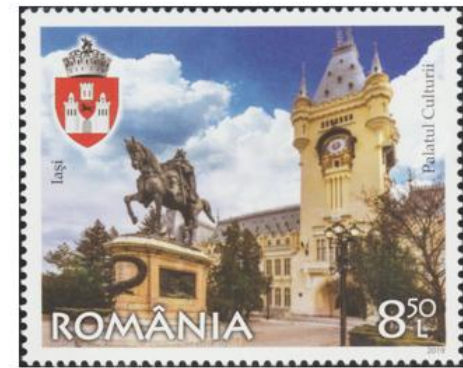

(e) Palace of Culture, Iași

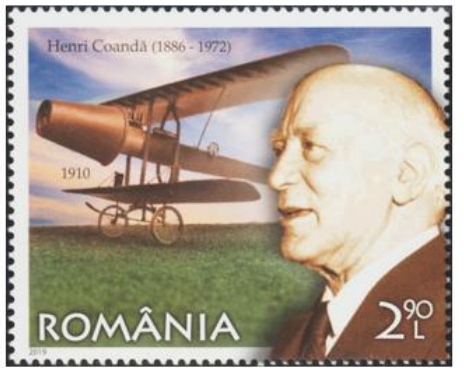

(c) Henri Coandă (1886-1972)

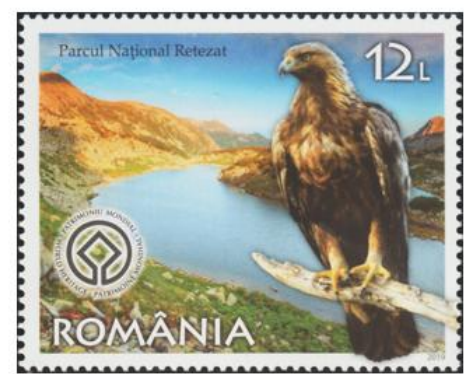

(f) Retezat National Park

Fig. 7. Postage stamps of the philatelic issue "Romania, a European treasure", 16.01.2019, Bucharest 
The city of lași, a historical and cultural landmark of the Romanian people, the place where the first Romanian postage stamp appeared over 160 years ago, the famous ox head, hosts in its center a real architectural jewel, the Palace of Culture. This building is illustrated on the stamp with a face value of 8.50 lei (Fig. 7e). Originally known as the Palace of Justice and Administration, the building is designed in the style of communal palaces in Western Europe, which combines several architectural styles. The clock with three dials in the tower of the building, decorated with small stained glass windows representing the twelve signs, is framed by the locals in national costume. Today, the Palace of Culture in lasi is home to the National Museum Complex "Moldova", where there are four other national museums - the Museum of History of Moldova, the Museum of Science and Technology "Stefan Procopiu", the Museum of Art and the Ethnographic Museum of Moldova.

The stamp with a face value of 12 lei illustrates the most important mountain nature reserve in Romania, Retezat National Park (Fig. 7f).

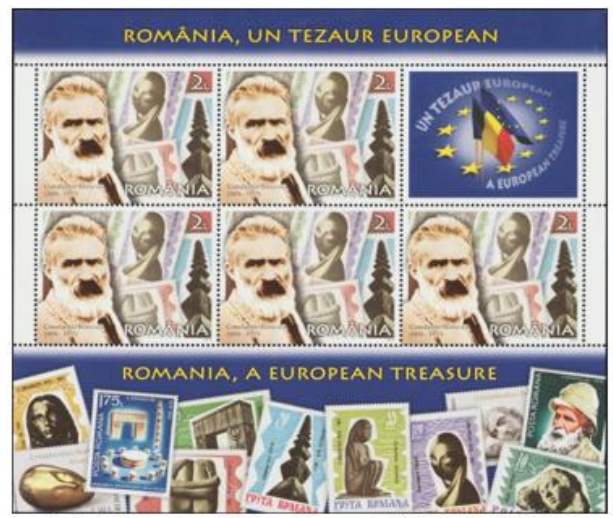

(a) Constantin Brâncuși (1876-1957)

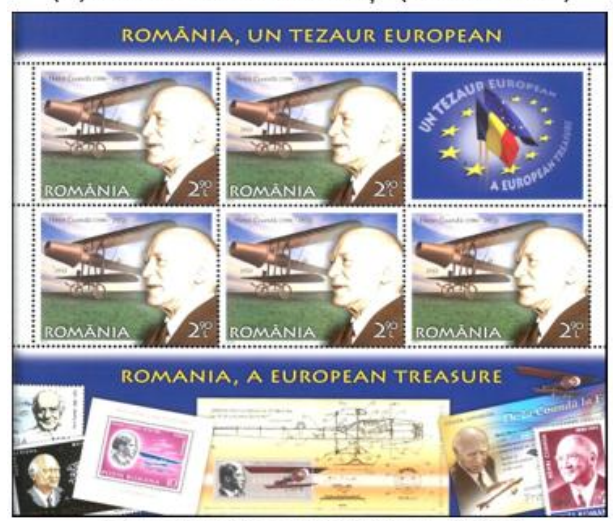

(c) Henri Coandă (1886-1972)
The UNESCO Committee, at the 6th session of the International Coordinating Council of the Man-Biosphere Program, in Paris in 1979, designated the Retezat National Park as a Biosphere Reserve. Thus, the invaluable wealth of our country was confirmed once again. Places still untouched by man, over 20 peaks higher than 2,000 meters, 80 lakes and lakes where the blue sky is reflected, flowers, glaciers, caves, wild animals, vast forests - all gather in a trembling world of life, in a unique monument of nature.

As usual, in this issue, we are talking about the blocks of $5+1$ postage stamps (see Fig. 8), a souvenir package with all 6 stamps (see Fig. 9a) [21], respectively the two FDCs equipped with the stamps of the show, numbered and obliterated with the stamp "the first day of the emission" (Fig. 9b-c) [22,23]. Furthermore, for some of the pieces of the show (more precisely the first three in the series) were identified maximum postcards, all 6 reproduced in Fig. 10, which were made in a private regime by the Romanian collector Alexandru Antonache [24].

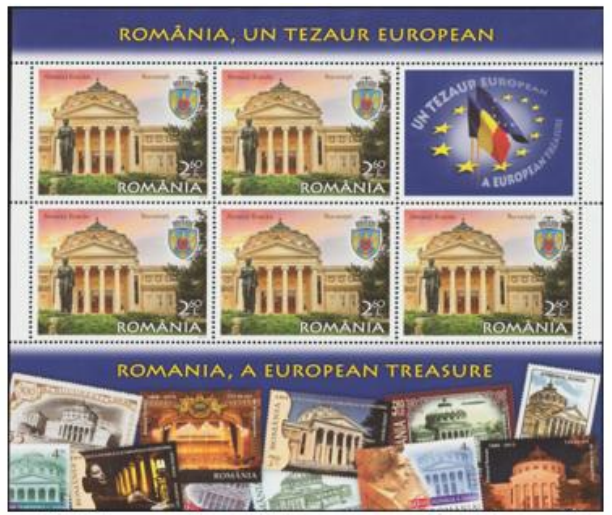

(b) Romanian Athenaeum, Bucharest

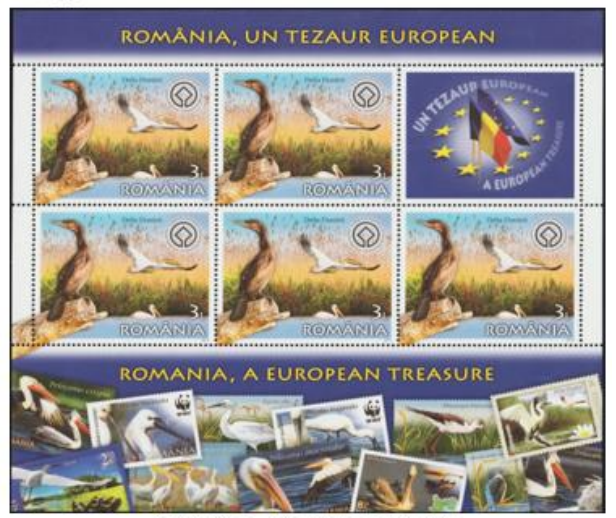

(d) The Danube Delta 


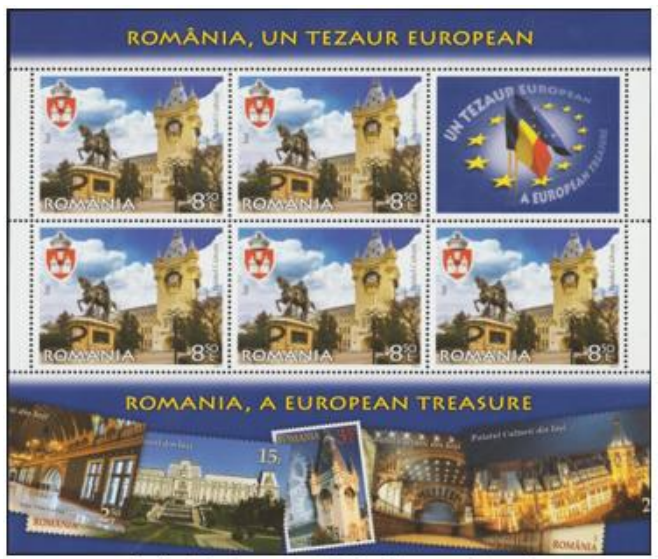

(e) Palace of Culture, lași

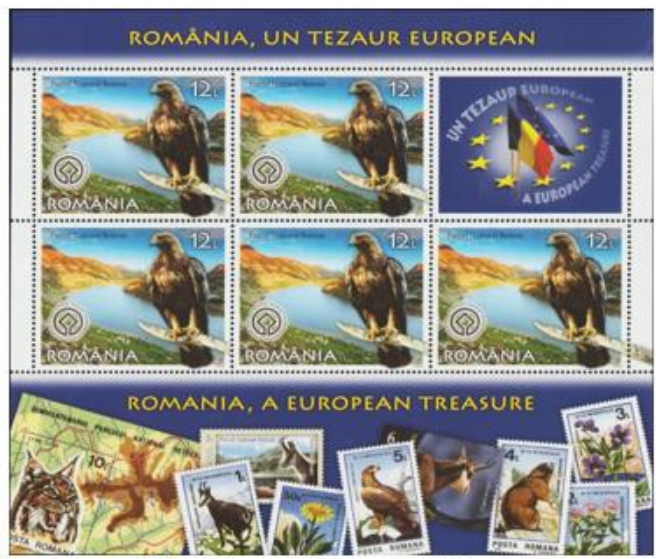

(f) Retezat National Park

Fig. 8. The blocks of $5+1$ postage stamps of the philatelic issue "Romania, a European treasure", 16.01.2019, Bucharest

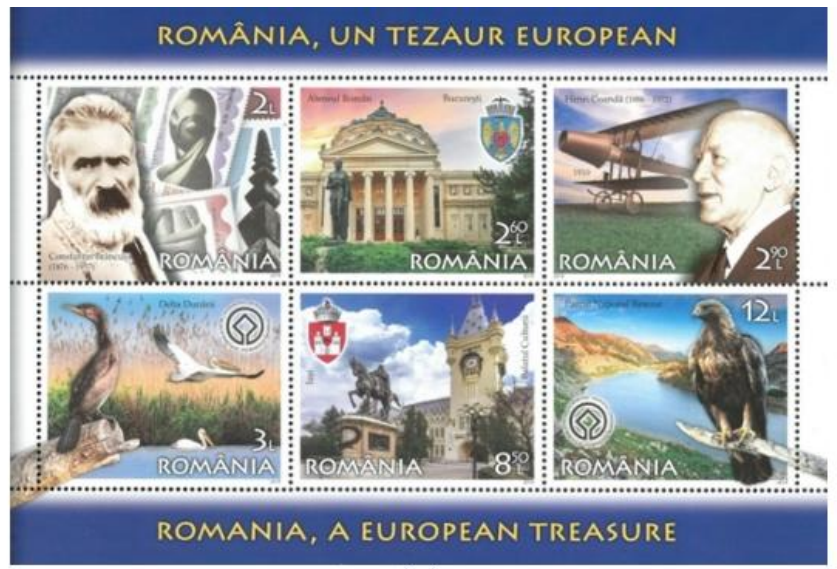

(a)

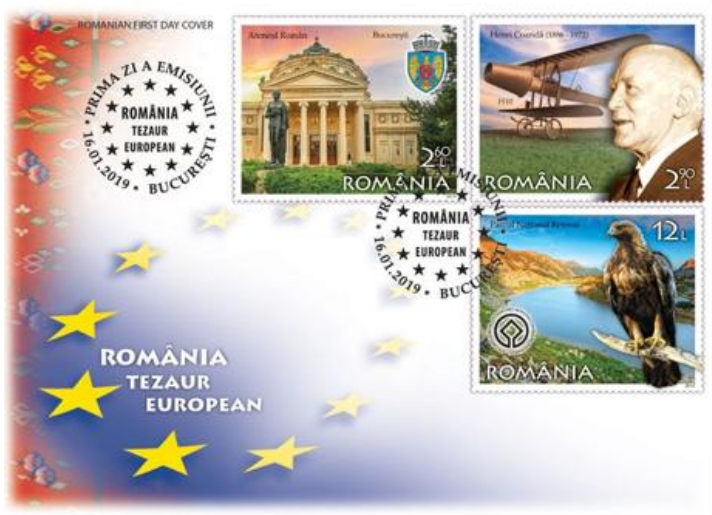

(b)

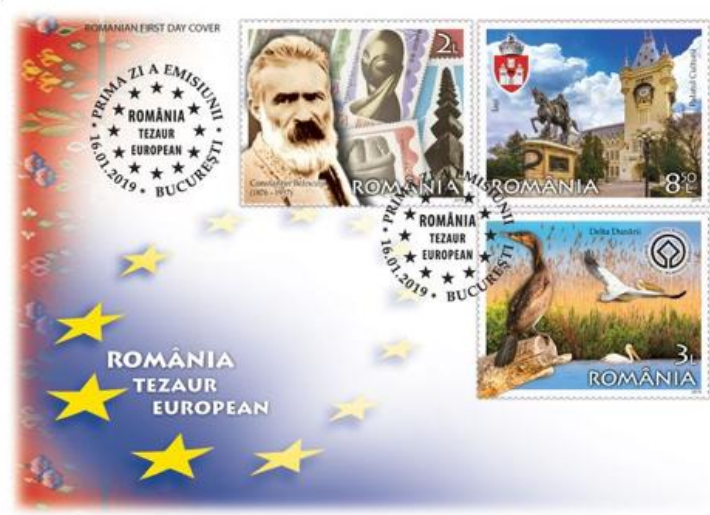

(c)

Fig. 9. 6-stamp souvenir package and the two FDCs of the philatelic issue "Romania, a European treasure", 16.01.2019, Bucharest 


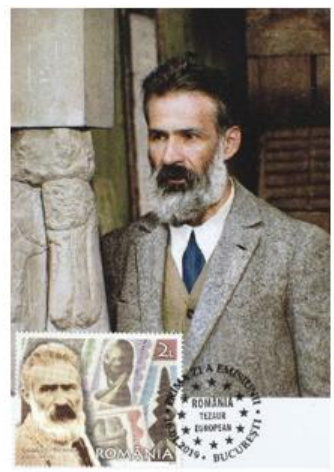

(a) Constantin Brâncuși (1876-1957)

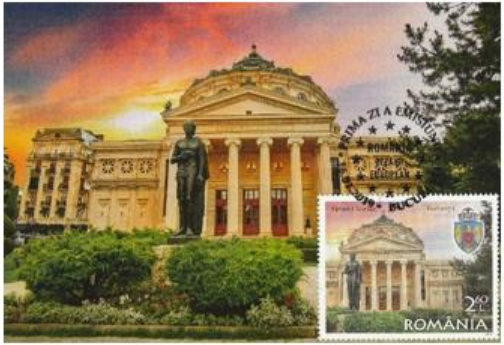

(b) Romanian Athenaeum, Bucharest

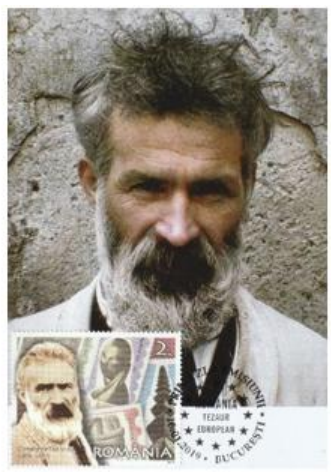

(c) Constantin Brâncuși (1876-1957)

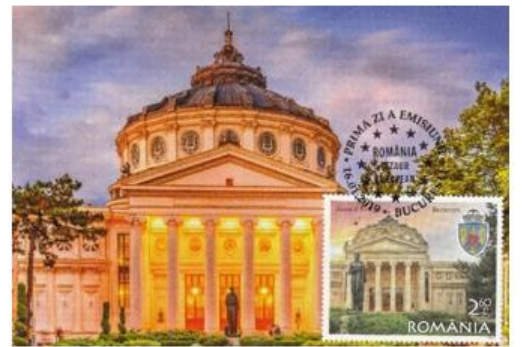

(d) Romanian Athenaeum, Bucharest

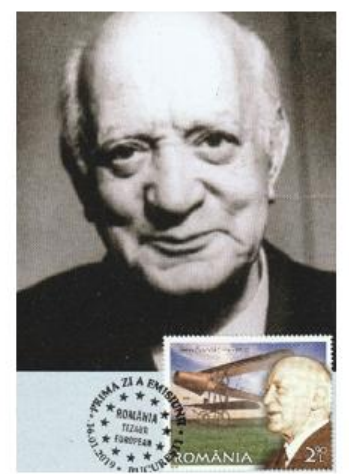

(e) Henri Coandă (1886-1972)

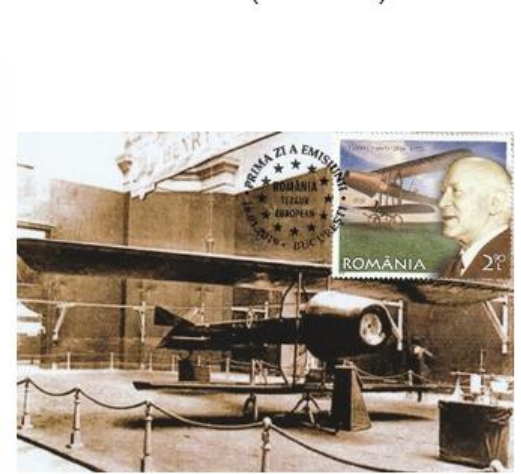

(f) Henri Coandă (1886-1972)

Fig. 10. Maximum postcards made in private regime with the stamps of the philatelic issue "Romania, a European treasure", 16.01.2019, Bucharest

In addition to the beauty of the support postcards themselves, the involvement of the stamps is also noticeable, which comes to emphasize the choice made by the author. It also highlights the similarity between the support and the piece that takes the place of posting.

\subsection{Welcome to Romania!, 2019}

Welcome to Romania! A traditional wish, addressed to guests eager to know the natural, spiritual, historical, and architectural beauties of Romania. To respond to this specific greeting to the local people, Romfilatelia introduced in circulation on 09.05.2019, a philatelic issue with the title of the mentioned wish - "Welcome to Romania!" (LP \#2239) [21], coinciding with Europe Day, also celebrated in Romania, as a state of the European Union.

The issue composed of 6 stamps, in $52 \times 42 \mathrm{~mm}$ format, was made according to a model belonging to $M$. Vămășescu, being paginated in a sheet of 20 stamps $(49,000$ stamps), mini- sheet of 5 stamps +1 vignette $(8,016$ mini-sheets, the equivalent of 40,080 stamps ), a block of 6 undamaged stamps - LP \#2239a (3,900 blocks, the equivalent of 23,400 stamps) and a lacy package - LP \#2239b (3,650 stamps), totaling a total circulation of 116,130 stamps $[25,26]$. The issue is also accompanied by 225 sets of 2 FDC envelopes, each, equipped with the issue's stamps, numbered and obliterated to the "first day of issue" stamp.

On the postage stamp with a face value of 1.60 lei is illustrated Sturdza Castle from Miclăușeni also known as Sturdza Palace (see Fig. 11a). It was built between 1880 and 1904 in the Gothic style by Gh. Sturdza and his wife Maria (born Ghica), on the site of an old mansion dating from 1755 . The exterior decorations of the castle show details of the coat of arms of Sturza, along with the emblem of the Castilian George A. Sturdza, inspired by the icon of Saint George. The interior of the castle has ceilings and walls painted in tempera with floral and geometric motifs, under the coordination of architect Julius Reinecke. After many unfortunately events that affected its beauty, but without erasing its inestimable value, it was rebuilt in 2004. 


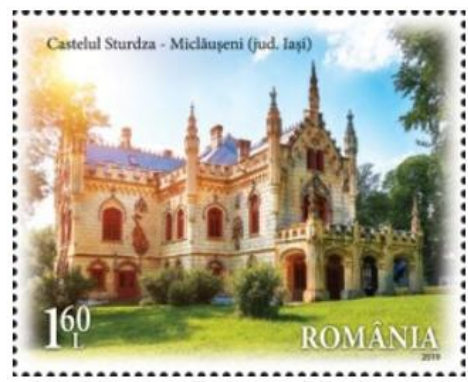

(a) Sturdza Palace, Miclăușeni (lași)

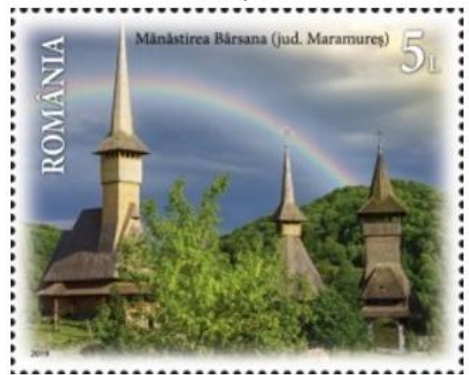

(d) Bârsana Monastery (Maramureș)

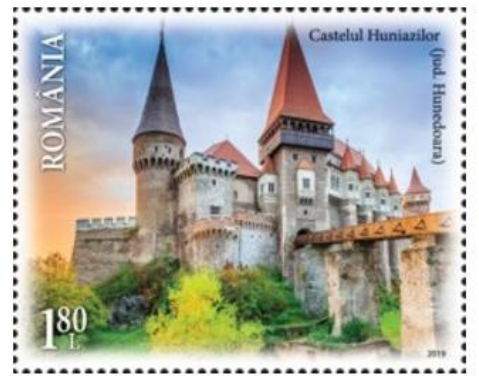

(b) Corvin Castle (Hunedoara)

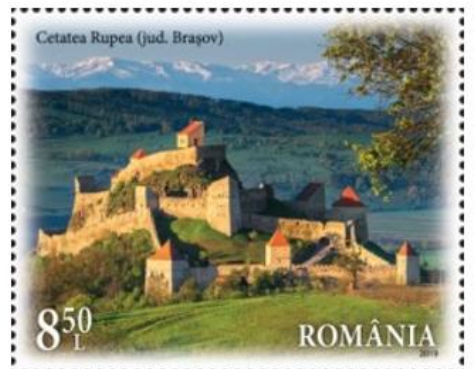

(e) Rupea Fortress (Brașov)

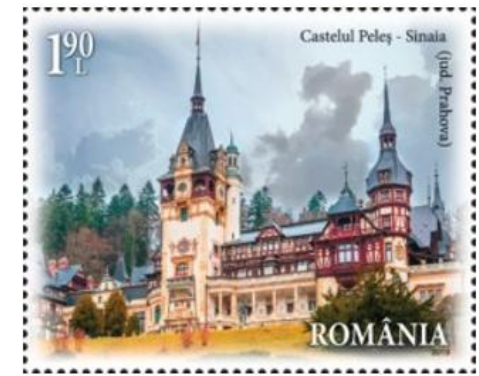

(c) Pêles Castle, Sinaia (Prahova)

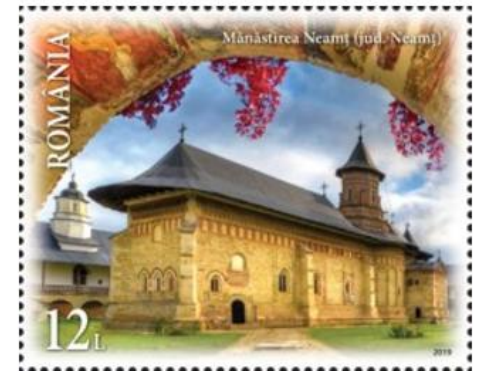

(f) Neamţ Monastery (Neamț)

Fig. 11. Postage stamps of the philatelic issue "Welcome to Romania!", 09.05.2019, Bucharest

The postage stamp with a face value of 1.80 lei represents the Huniazilor Castle, one of the most important monuments of Gothic architecture and feudal art in Romania and Europe, impressed with its various architectural styles and legends woven around it (see Fig. 11b).

Impressive construction with towers and bastions, the castle was built by lancu de Hunedoara in the 15th century, on the site of an old Roman camp. Huniazilor Castle is one of the most beautiful and well-preserved buildings of the medieval era, being the most important real estate of lancu de Hunedoara, the first attestation of the castle dating from 1443. The most significant parts of the building have remained unchanged in terms of architecture since the time of lancu de Hunedoara, such as the Capistrano Tower (named after a famous Franciscan monk, loan de Capistrano), the suspended gallery, and the Neboisa tower.

The postage stamp with a face value of 1.90 lei shows the Peles Castle in Sinaia, rightly considered the "Pearl of the Crown" and one of the most beautiful castles in Romania (see Fig. 11c). From the very beginning, it was intended to be a royal summer residence. In August 1875, at the ceremony of laying the foundation stone of the castle, King Carol I said: "Let this castle be built and be well finished, so that it may become the cradle of my dynasty, of the national dynasty." The foundation deed and the deed of construction were built in the foundations, together with some coins with the effigy of Carol I. The castle is located on the bank of the Peles stream. In the over 150 rooms of Peles Castle, we meet different styles that blend harmoniously: Germanic, Italian, Gothic, German Baroque, Austrian, Turkish, and French Rococo renaissance. With several over 4000 pieces, the collection of parade and hunting weapons is among the largest in Europe.

The postage stamp with a face value of 5 lei shows the Bârsana Monastery, located in the historic Maramureș, in the Iza valley and built-in 1711 on the site of an old monastery whose history begins with the documentary attestation of Bârsana, from 1326 (see Fig. 11d). Unfavorable circumstances caused it to be moved twice until 1795 when it was placed in the middle of a cemetery for the victims of the plague. The interior was repainted by Hodor Toader in 1806, the paintings were executed on wood, the walls being leveled with textile pieces, fixed on the walls and covered with lime. The monastic ensemble was built under the coordination of Arch. Cordoș Dorel includes a Maramureș gate, the bell tower, the church with 
a height of 57 meters, the summer altar, the chapel built on several levels, the monks' cells, the masters' house, and the artists' workshop. The UNESCO World Heritage List includes eight wooden churches that were built between the 14th and 18th centuries.

On the postage stamp with a face value of 8.50 lei, the Rupea Fortress stands out, a historical monument representative of Brașov County, documented since 1324, being the refuge of the Saxons in the way of the armies of King Carol Robert of Anjou of Hungary (see Fig. 11e). The towers were built to perform defensive functions, and their historical development shows various architectural features. The walls of the fortress have been largely preserved, but they lack decorations that must have been made of wood, as can be seen at the Tower.

The postage stamp with a face value of 12.00 lei distinguishes the Neamt, Monastery, which is part of the national artistic and historical heritage, being called "Jerusalem of Romanian Orthodoxy" (see Fig. 11f). It plays a special role in the Romanian religious culture due to its

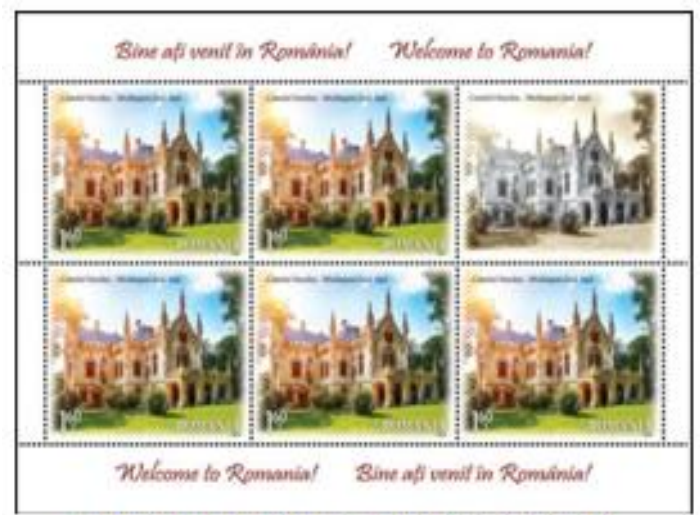

(a) Sturdza Palace, Miclăușeni (lași)

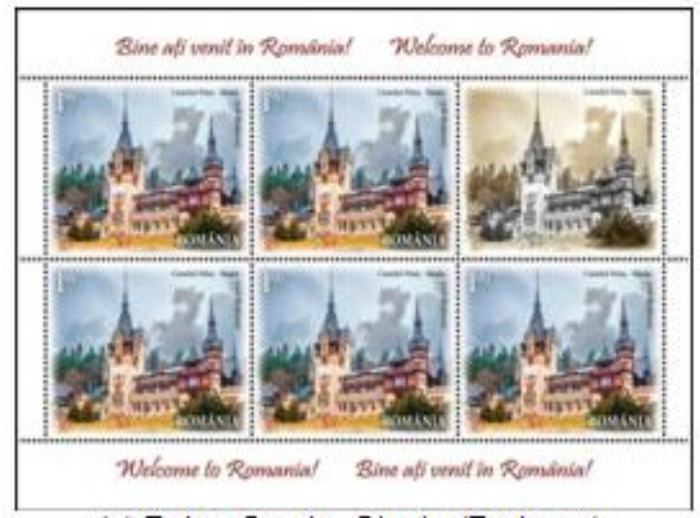

(c) Peleș Castle, Sinaia (Prahova) greatness and beauty. It is distinguished as one of the most interesting and representative monuments of the architecture of the XIV-XV centuries, both from the point of view of the plan and from the point of view of the mastery of decoration. The polychrome elements of the facade are enriched with glazed brick surrounding the monument, along with the buttresses specific to Moldovan architecture. The windows have been enlarged over the years, but since the restoration in 1958-1961, they have been restored to their original shape. The place of worship also has the oldest monastery library, totaling 18,000 volumes, of great importance for medieval Romanian culture and art.

With the lacy package of the show with a face value of $28.50 \mathrm{lei}$, it is illustrated the panoramic image of the urban space known as the Great Square, on the City Hall of Sibiu in the foreground (see Fig. 13a), as an emblematic building for the city of Sibiu, the host location of Informal Summit of Heads of State or Government of the European Union, held on 9 May 2019 [21,27-29].

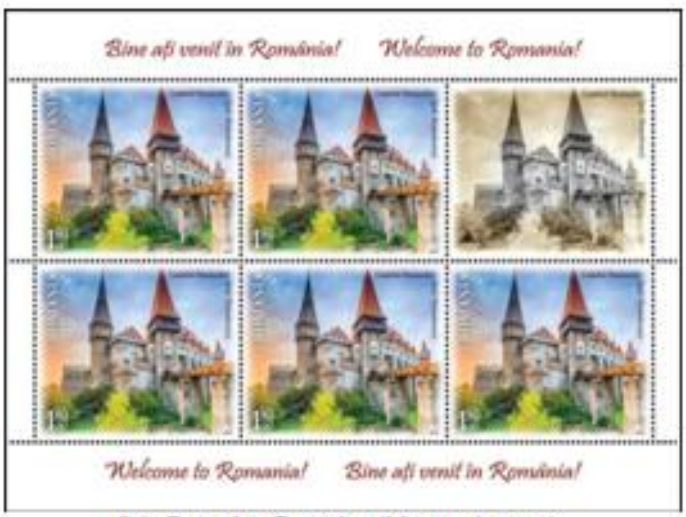

(b) Corvin Castle (Hunedoara)

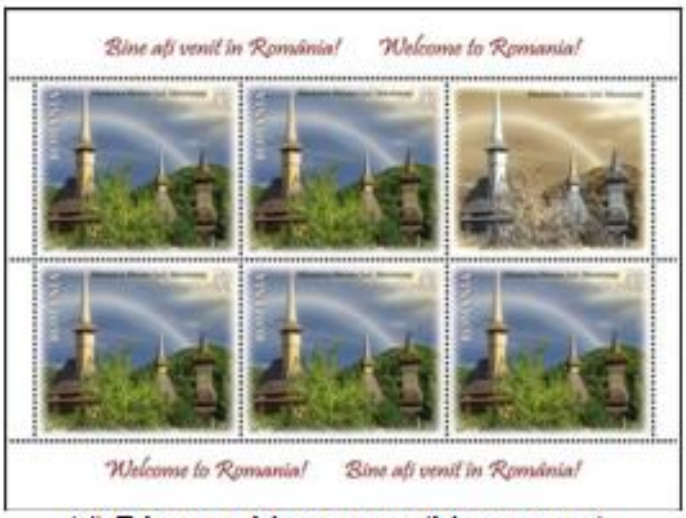

(d) Bârsana Monastery (Maramureș) 


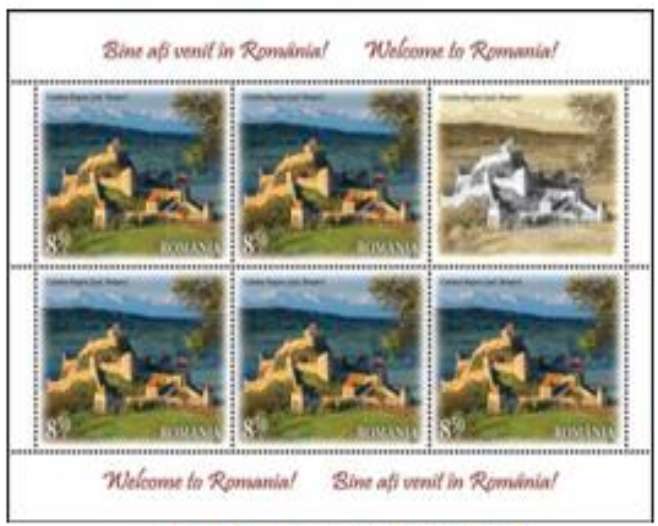

(e) Rupea Fortress (Brașov)

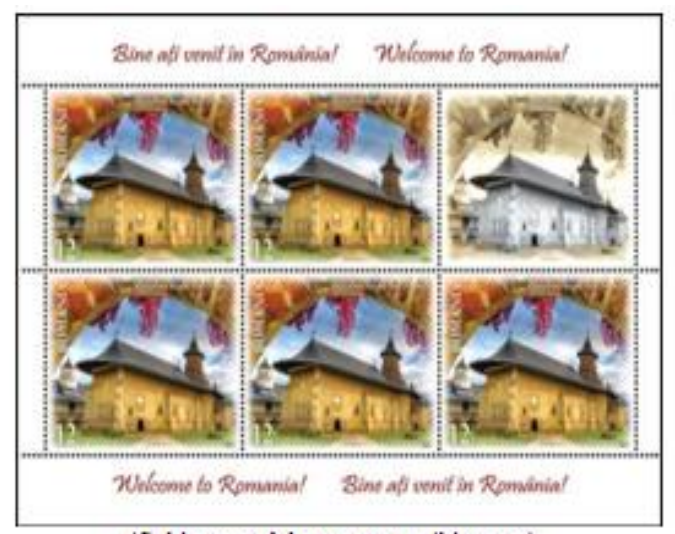

(f) Neamţ Monastery (Neamt)

Fig. 12. The blocks of $5+1$ postage stamps of the philatelic issue "Welcome to Romania!", 09.05.2019, Bucharest

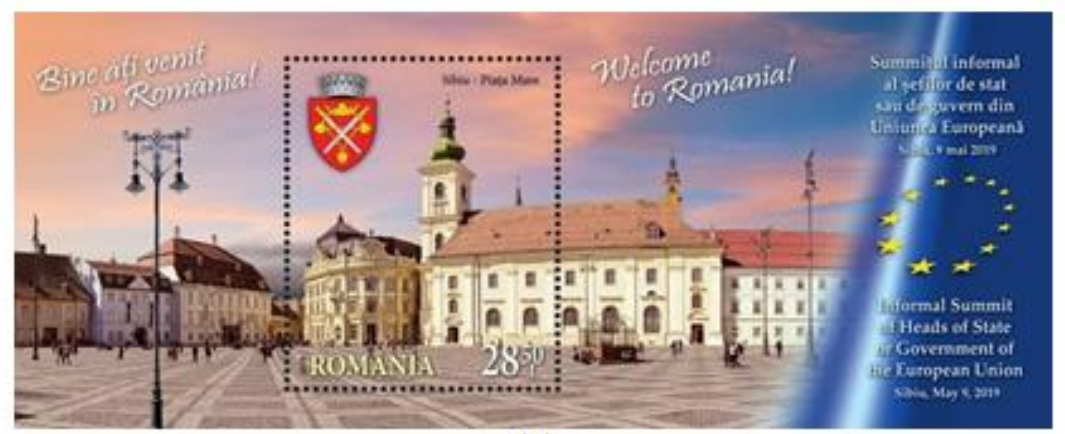

(a)

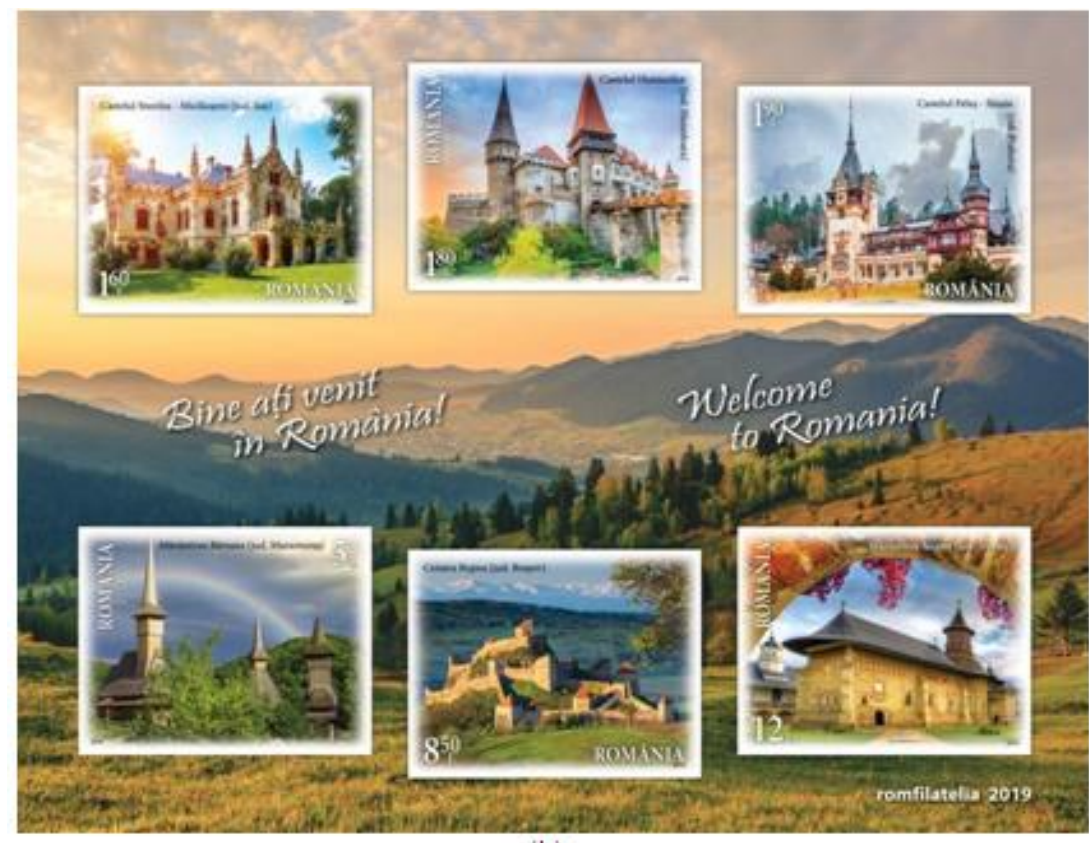

(b) 


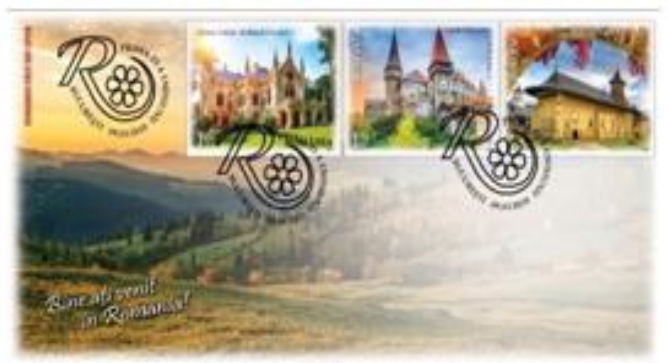

(c)

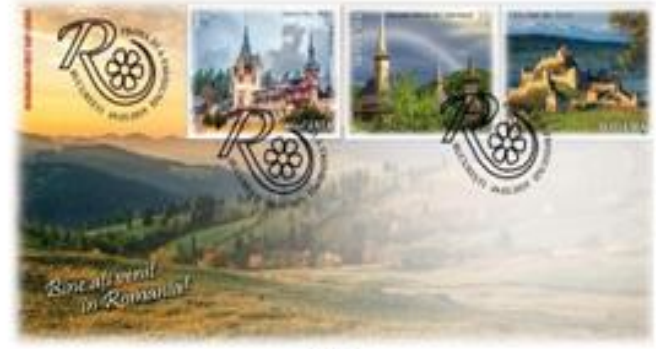

(d)
Fig. 13. Postage stamps of the philatelic issue

As you can see, the reproduced parts are of exceptional quality. They bear the imprint of the Romfilatelia company and come to recertify the real tourist value of Romania. They also capture the interest of potential tourists, who are waiting to find the same beauty in reality. Or it exists, the monuments reproduced at the level of the stamps, being the ones that Romanians enjoy every day.

\section{CONCLUSION}

Through this work, an attempt was made to bring to the fore the main philatelic issues that illustrate and treat very meticulously the cultural values of Romania. The pieces that are the object of the present study, published under the auspices of the Romfilatelia company, were in turn identified, indexed, and described. It is more than obvious that thematic philately has promoted and still promotes cultural values and their related tourism.

Unfortunately, although the objectives of the research were met by identifying, exposing, and analyzing the philatelic pieces under the theme "Welcome to Romania!", the problem of promotion in the literature remains. No similar scientific articles have been identified prior to the present one, which present or debate the idea of promoting Romania's cultural values from a philatelic point of view. Besides this aspect, there were also limitations in carrying out the present study, from the perspective of the defective indexing of the philatelic material, of the interference with other pieces or of the lack of some valuable technical information. As a recommendation, it is proposed in this sense the use of several sources of information, including discussions with collectors and philatelists, respectively, the framing of such thematic pieces in specialized articles.

\section{COMPETING INTERESTS}

Author has declared that no competing interests exist.

\section{REFERENCES}

1. Anonymous. Romania - Carpathian Garden. Romfilatelia. Accessed on 02.10.2020.

Available: www.romfilatelia.ro/ro/romaniagradina-carpatilor. Romanian.

2. Cioruța B, Pop AL, Coman M. On the philatelic circuit of the UNESCO churches from Maramureș. Asian Journal of Education and Social Studies (AJESS ${ }^{\circledR}$ ). 2020;13(3):60-84.

Available:www.journalajess.com/index.php /AJESS/article/view/30335

3. Anonymous. EUROPE 2012 - Visit Romania. Romfilatelia. Accessed on 05.10.2020.

Available: www.romfilatelia.ro/ro/europa2012-vizitati-romania. Romanian.

4. Anonymous. Romania - a European treasure. Romfilatelia. Accessed on 05.10.2020.

Available:www.romfilatelia.ro/ro/romaniaun-tezaur-european. Romanian.

5. Tudor GH, Chiricheş C, Mermeze GH. Catalog of Romanian postage stamps 1990-2017 (LP \#1233-2135), Editura AXA, Bucureşti; 2017. Romanian.

6. Scăiceanu C. Catalog of layout designers of Romanian postage stamps, Oscar Print Publishing House, Bucharest; 2018. Romanian.

7. Anonymous. Romania - a European treasure. Colnect; 20220

Accessed on 05.10.2020. Available:https://colnect.com/en/stamps/list /country/177-Romania/series/66474- 
Romania -

A_European_Treasure/year/2009

8. Anonymous. Romania - a European treasure. StampWorld. Accessed on 05.10.2020.

Available:www.stampworld.com/stamps/R omania/Postage-stamps/g6373

9. Available:www.delcampe.net/en_US/collec tibles/stamps/romania-1948-

republics/unused- stamps-5/2009-romaniaa-european-treasure-set-set-of-sheetlets-iii-minr-6385-6392- wine-castle-flora-andfauna-music-1039978891.html

10. Available:www.delcampe.net/en_US/collec tibles/stamps/romania-1948republics/unused- stamps-5/roumanieromania-2009-yvertn-5381-5388-mnhcote-17-60-euro-595076395.html

11. Available:www.delcampe.net/en_US/collec tibles/stamps/organizations/europeancommunity/european-central-bank-culturaldays-cover-stationery-entier-postaux-oblitfdc-2009-romania-291749949.html

12. Available:www.delcampe.net/en_US/collec tibles/stamps/music/618fm-goergeenescu- composer-cultural-days-coverstationery-2009-romania-289903025.html

13. Available:www.delcampe.net/en_US/collec tibles/stamps/romania/postal-

stationery/cultural- days-european-bankcover-stationery-entier-postal-2009romania-266627277.html

14. Available:www.delcampe.net/en_US/collec tibles/stamps/drinks/wines-

alcohols/romania-2009- postal-stationerycover-vines-grapes-85144105.html

15. Anonymous. Welcome to Romania!. Romfilatelia. Accessed on 07.10.2020. Available:www.romfilatelia.ro/ro/bun-venitin-romania. Romanian.

16. Anonymous. Welcome to Romania!. Colnect. Accessed on 07.10.2020.
Available:https://colnect.com/en/stamps/list /country/177-Romania/series/292311-

Welcome_to_Romania/year/2017

17. Available:Anonymous. Welcome to Romania!. StampWorld. Accessed on 07.10.2020. Available: www.stampworld.com/stamps/Romania/Po stage-stamps/g7239

18. Available:www.romfilatelia.ro/ro/romaniaun-tezaur-european-2

19. Available:https://colnect.com/ro/stamps/list /country/177-

Rom\%C3\%A2nia/series/343289-

Romania_A_European_Treasure/year/201 9

20. Available:www.stampworld.com/stamps/R omania/Postage-stamps/g7476

21. Available:http://romfilatelia.ro/magazin/pro dus/colectii-anuale/bine-ati-venit-inromania

22. Available:https://www.romfilatelia.ro/en/first -day-covers/page/3

23. Available:https://blog.citatepedia.ro/romani a-un-tezaur-european.htm

24. Available:https://alexantonache.wordpress. com/2019/01/20/romania-un-tezaureuropean

25. Available:https://colnect.com/ro/stamps/list /country/177-

Rom\%C3\%A2nia/series/357332-

Welcome_to_Romania_2019/year/2019

26. Available:www.stampworld.com/stamps/R omania/Postage-stamps/g7531

27. Available:www.stampworld.com/stamps/R omania/Postage-stamps/g7537

28. Available:www.freestampcatalogue.com/sr op31914a-welcome-to-romania-6v-m-simperforated

29. Available:http://philamirror.info/2019/05/13/ new-stamps-issued-fromromania/romania-welcome- stamps

(c) 2021 Cioruța; This is an Open Access article distributed under the terms of the Creative Commons Attribution License (http://creativecommons.org/licenses/by/4.0), which permits unrestricted use, distribution, and reproduction in any medium, provided the original work is properly cited.

Peer-review history:

The peer review history for this paper can be accessed here: http://www.sdiarticle4.com/review-history/65276 